\title{
pArsitektur Konsolidasi Server dengan Virtualisasi untuk Penyedia Layanan Infrastruktur Cloud
}

\author{
I Gusti Ngurah Wikranta Arsa \\ Institut Teknologi dan Bisnis (ITB) STIKOM Bali \\ e-mail: arsa@stikom-bali.ac.id \\ Diajukan: 24 Oktober 2019; Direvisi: -; Diterima: 15 November 2019
}

\begin{abstract}
Abstrak
IAAS sebagai salah satu model layanan penyedia infrastruktur tentunya harus melayani kebutuhan infrastruktur khususnya server sebagai salah satu layanan komputasi. Dalam implementasinya layanan penyedia server atau komputasi memberikan sebuah server yang dapat dikelola oleh pengguna layanan, sebagai penyedia layanan seharusnya menyediakan server secara fisik. Permasalahan yang ditimbulkan adalah jumlah server yang disediakan tentunya sesuai dengan jumlah pelanggan jika saja ini dilakukan maka akan menimbulkan jumlah server yang banyak dan tingkat investasi yang besar, konsumsi daya yang besar, penggunaan utilitas infrastruktur yang tidak maksimal, biaya perawatan besar, penyediaan ruang secara fisik yang besar, serta manajemen pengelolaan perangkat fisik yang besar. Dalam pengelolaannya ada beberapa metode yang bisa dilakukan salah satunya adalah dengan konsolidasi. arsitektur server konsolidasi yang digunakan untuk penyedia layanan infrastructure cloud computing. Dimana pada arsitektur terdapat tiga layer yang diusulkan yaitu layer infrastruktur sebagai penyedia fisik dari server, layer hypervisor sebagai sistem oprasi virtualisasi pengelola seluruh infrastruktur fisik, dan yang ketiga adalah layer aplikasi yang berisikan seluruh mesin virtual yang dapat diakses oleh pengguna layanan cloud infrastruktur.
\end{abstract}

Kata kunci: Konsolidasi server, Cloud computing, Hypervisor.

\begin{abstract}
IAAS as one of the infrastructure service provider models must of course serve the infrastructure needs, especially servers as one of the computing services. In its implementation, the server or computing service provider provides a server that can be managed by the service user, as the service provider should provide a physical server. The problem that arises is the number of servers provided is certainly in accordance with the number of customers if this is done it will lead to a large number of servers and a large investment level, large power consumption, use of infrastructure utilities that are not optimal, large maintenance costs, provision of physical space large, as well as the management of large physical devices. In its management there are several methods that can be done, one of which is by consolidation. Consolidated server architecture used for cloud computing infrastructure service providers. Where in the architecture there are three proposed layers, namely the infrastructure layer as the physical provider of the server, the hypervisor layer as the operating virtualization system that manages all physical infrastructure, and the third is the application layer which contains all virtual machines that can be accessed by users of the infrastructure cloud service.
\end{abstract}

Keywords: Server consolidation, Cloud computing, Hypervisor.

\section{Pendahuluan}

Salah satu model layanan cloud computing adalah IAAS (Infrastructure As A Service) di mana dalam implementasinya sering disebutkan sebagai penyedia layanan komputasi. Dalam penyedia layanan komputasi tentunya dibutuhkan infrastruktur yang andal. Penyediaan infrastruktur yang andal membutuhkan berbagai pertimbangan seperti optimasi biaya, kompleksitas, komunikasi, keamanan, legalitas, konsumsi daya, dan lainya. Hal ini juga tidak lepas dari solusi investasi perangkat yang baik.

IAAS sebagai salah satu model layanan penyedia infrastruktur tentunya harus melayani kebutuhan infrastruktur khususnya server sebagai salah satu layanan komputasi. Dalam implementasinya layanan penyedia server atau komputasi memberikan sebuah server yang dapat dikelola oleh pengguna layanan, sebagai penyedia layanan seharusnya menyediakan server secara fisik. Permasalahan yang ditimbulkan 
adalah jumlah server yang disediakan tentunya sesuai dengan jumlah pelanggan jika saja ini dilakukan maka akan menimbulkan jumlah server yang banyak dan tingkat investasi yang besar, konsumsi daya yang besar, penggunaan utilitas infrastruktur yang tidak maksimal, biaya perawatan besar, penyediaan ruang secara fisik yang besar, serta manajemen pengelolaan perangkat fisik yang besar. Selain itu diperlukan juga tingkat kinerja dari server. Dalam pengelolaannya ada beberapa metode yang bisa dilakukan salah satunya adalah dengan konsolidasi.

Konsolidasi server adalah teknik yang dibangun dengan memasukkan sejumlah virtual mesin ke dalam sebuah server fisik dengan tepat dan dapat digabungkan menjadi satu servis [1]. Konsolidasi dapat diartikan juga melakukan sentralisasi beban kerja dalam hal ini beberapa server virtual sebagai layanan IAAS ke dalam sebuah server fisik yang bertujuan untuk mengurangi biaya. Konsolidasi Server adalah salah satu alasan utama penyedia layanan cloud dalam menerapkan virtual mesin dan menjadikan beberapa penelitian khususnya migrasi virtual mesin untuk server konsolidasi [2]. Konsolidasi server bertujuan untuk meningkatkan efisiensi pemanfaatan sumber daya komputer dengan mengurangi jumlah server di mana semua fungsi yang sebelumnya ditangani beberapa server berbeda dapat ditangani oleh satu server dengan kapasitas yang lebih besar [3]. Konsolidasi server memiliki tingkat kerumitan yang tinggi, salah satu teknik yang sering digunakan untuk implementasi metode konsolidasi server adalah virtualisasi. Konsolidasi server tentunya memiliki kelemahan dan keuntungan dari berbagai sisi, salah satunya adalah kinerja dari server konsolidasi ataupun efisiensi jika digantikan dengan teknik konsolidasi yaitu server secara virtualisasi.

Teknologi virtualisasi banyak digunakan untuk modern data senter karena mudah dalam memanajemen dan menekan konsumsi energi. Teknologi virtualisasi memungkinkan migrasi langsung mesin virtual, yang memungkinkan virtual mesin untuk dipindahkan secara bebas di antara mesin-mesin fisik dengan down time yang dapat diabaikan. Dengan demikian, beberapa virtual mesin dapat dikemas pada satu mesin fisik tunggal sehingga membiarkan mesin fisik berjalan dalam kondisi kerja yang lebih hemat energi. Teknik ini disebut konsolidasi server dan merupakan pendekatan yang efektif dan banyak digunakan untuk mengurangi konsumsi energi total di pusat data [4].

Salah satu hypervisor yang dapat digunakan untuk virtualisasi adalah Proxmox VE. Proxmox VE merupakan sebuah proyek open source yang dikembangkan dan di-maintain oleh Proxmox Server Solution $\mathrm{GmbH}$ di Jerman. Proxmox VE adalah sebuah platform virtualisasi open source untuk menjalankan appliance dan mesin virtual [5]. Proxmox menggunakan kernel Linux dan didasarkan pada distro GNU/Linux Debian. Source code Proxmox VE dirilis berdasarkan GNU Affero General Public License, versi 3 (GNU AGPL,v3). Yang berarti bebas untuk memeriksa source code setiap saat dan berkontribusi pada Proxmox. Proxmox VE menggunakan KVM (Kernel-base Virtualization Machine). Open source hypervisor KVM adalah salah satu solusi full virtualization untuk Linux dalam perangkat keras x86 yang berisi ekstensi virtualisasi (Intel VT atau AMD-V). Ini adalah modul kernel yang ditambahkan ke dalam main-line Linux. Dengan KVM memudahkan dalam menjalankan beberapa virtual mesin dengan unmodified Linux atau images Windows.

Saat ini pusat data cloud modern mengeksploitasi virtualisasi sebagai salah satu cara memanajemen sumber daya yang efisien untuk mengurangi beban penyediaan komputasi dan energi. Virtualisasi yang banyak digunakan adalah Virtual Mesin (VM) yang direlokasi ke dalam cloud data senter. Perpindahan menuju VM sangat membantu dalam mencapai berbagai objek dalam manajemen sumber daya di antaranya load balancing, manajemen daya, toleransi kesalahan, dan pemeliharaan sistem [6]. Selain itu menurut [7] kebutuhan skala pusat data cloud menjadi semakin membesar, konsumsi energi pusat data juga tumbuh dengan cepat. Konsolidasi dinamis Mesin Virtual (VM) menghadirkan peluang signifikan untuk menghemat energi dengan mematikan Mesin Fisik yang menganggur atau kurang dimanfaatkan di pusat data, hal ini menunjukkan konsolidasi server menjadikan salah satu usulan dalam menangani konsumsi daya yang hemat. Virtualisasi server dan konsolidasi beban kerja memungkinkan banyak beban kerja untuk berbagi satu server fisik, menghasilkan penghematan energi dan peningkatan pemanfaatan yang signifikan. Karena itu [8] melakukan penelitian yaitu mengkarakterisasi konsolidasi beban kerja cloud pada sistem virtualisasi NUMA, memperkirakan empat sumber overhead arsitektur yang berbeda, dan mengeksplorasi peluang pengoptimalan di luar default manajemen memori NUMA-aware hypervisor.

\section{Metode Penelitian}

Dalam Penelitian ini dilakukan beberapa langkah-langkah mulai dari investigasi masalah, analisis konsolidasi server, perancangan arsitektur, implementasi, pengujian server konsolidasi, dan analisis akhir. Dapat dilihat pada Gambar 1 


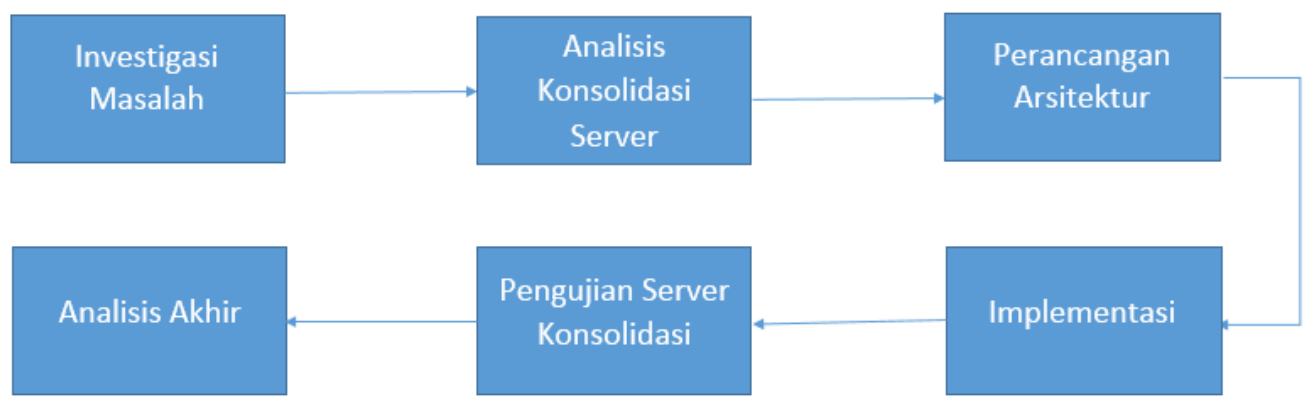

Gambar 1. Sistematika Penelitian

Tahap pertama dalam penelitian ini adalah investigasi masalah. Yang menjadi masalah kenapa penelitian ini dilakukan adalah jumlah server yang disediakan tentunya sesuai dengan jumlah pelanggan jika saja ini dilakukan maka akan menimbulkan jumlah server yang banyak dan tingkat investasi yang besar, konsumsi daya yang besar, penggunaan utilitas infrastruktur yang tidak maksimal, biaya perawatan besar, penyediaan ruang secara fisik yang besar, serta manajemen pengelolaan perangkat fisik yang besar. Selain itu diperlukan juga tingkat kinerja dari server.

Tahap selanjutnya adalah analisis konsolidasi server, pada tahap ini dilakukan analisis mengenai konsolidasi server, apa konsolidasi server, seperti apa pengaplikasian dari konsolidasi server. Tahap ini lebih banyak melakukan pendalaman materi dengan melakukan beberapa studi literatur dan beberapa pengaplikasian server konsolidasi.

Tahap ketiga adalah perancangan arsitektur, pada tahap ini dirancang infrastruktur, instalasi bagaimana sebuah penyedia layanan server. Selanjutnya dilihat seperti apa pengaplikasian dan tentunya arsitektur yang akan dihasilkan dalam penelitian berdasarkan dari instalasi server. Tahap ini menghasilkan sebuah arsitektur server konsolidasi.

Tahap keempat adalah implementasi, tahap ini adalah pengimplementasian dari sistem penyedia layanan cloud server atau cloud infrastruktur berdasarkan dari arsitektur yang diusulkan. Implementasi di sini akan menggunakan Proxmox VE sebagai hypervisor yang dapat menghasilkan server virtual. Proxmox VE berbasis Linux Debian yang open-source. Kemudian nantinya dibuatkan beberapa server virtual yang berjalan pada satu server fisik. Pada implementasi direncanakan menggunakan 2 server fisik dan 5-10 virtual mesin akan dibuat

Tahap kelima adalah pengujian server konsolidasi, dalam tahap ini akan dilakukan pengujian kinerja server konsolidasi. Dilihat sejauh mana kinerja server yang dihasilkan pada dari arsitektur yang dirancang. Kinerja server adalah sejauh mana server dapat menangani beban kerja sesuai dengan pengujian. Pengujian yang dilakukan seperti kinerja server dan CPU utilization untuk melihat sejauh mana efektivitas sebuah server konsolidasi bekerja. Selanjutnya dilihat juga perbandingan efisiensi kinerja dari mesin fisik.

Tahap terakhir adalah analisis akhir, pada tahap ini dilakukan analisis dari hasil pengujian. Analisis akhir ini memberikan laporan berupa grafis hasil dari pengujian dan penjelasan kinerja yang dihasilkan dari server konsolidasi.

Data yang digunakan pada penelitian ini bersumber dari beberapa literatur dan untuk pengujian menggunakan data yang ada pada sistem operasi Linux. Data tersebut digunakan untuk pengujian. Data akan di kompresi, kompresi dilakukan karena proses kompresi memerlukan perhitungan matematika yang tentunya membebani prosesor untuk bekerja.

Pengumpulan data adalah teknik atau cara yang dilakukan oleh peneliti untuk mengumpulkan data. Pengumpulan data dilakukan untuk memperoleh informasi yang dibutuhkan dalam rangka mencapai tujuan penelitian. Dalam penelitian ini digunakan teknik observasi dan studi dokumen.

Observasi adalah metode pengumpulan data yang kompleks karena melibatkan berbagai faktor dalam pelaksanaannya. Metode pengumpulan data observasi tidak hanya mengukur sikap dari responden, namun juga dapat digunakan untuk merekam berbagai fenomena yang terjadi. Dari hasil observasi dan pengal aman dal am pembuatan model cloud laaS. Sudah ada beberapa perusahaan besar yang menyediakan infrastruktur IT seperti Amazone EC2, Google, Microsoft, dan lainnya. Namun tentunya perusahaan tersebut memiliki kapasitas dan target pasar yang menyasar perusahaan yang besar. Hal ini menjadi pertimbangan juga dal am pembuatan sistem yang cloud.

Kemudian observasi selanjutnya adalah melihat fenomena penggunaan infrastruktur cloud mulai menjadi solusi yang menjanjikan. Beberapa perusahaan atau start-up sudah mulai menggunakan jasa penyediaan server secara cloud. Hal ini juga menjadikan cloud mulai diminati beberapa perusahaan kecil

Arsitektur Konsolidasi Server dengan Virtualisasi untuk Penyedia Layanan Infrastruktur Cloud (I Gusti Ngurah Wikranta Arsa) 
menengah. Selain itu banyak aplikasi atau sistem yang menawarkan model layanan software as a service tentunya menjadikan gaya berkomputasi yang baru.

Studi Dokumen metode pengumpulan data yang tidak ditujukan langsung kepada subjek penelitian. Studi dokumen adalah jenis pengumpulan data yang meneliti berbagai macam dokumen yang berguna untuk bahan analisis. Dalam studi dokumentasi digunakan beberapa paper dari berbagai sumber yang berkaitan tentang Server Konsolidasi, virtualisasi, analisis kinerja server, dan beberapa teknik yang digunakan dalam menguji kinerja beberapa server. studi dokumen digunakan untuk mempertimbangkan model atau arsitektur layanan cloud infrastruktur, platform atau hypervisor yang dapat digunakan, dan anal isis yang dapat digunakan.

Teknik analisis yang digunakan adalah kuantitatif. Di mana nanti data akan diambil dari hasil pengujian dan pengukuran dalam angka. Hasil pengambilan data dengan pengujian ini nantinya akan dianalisis berdasarkan data angka yang diperoleh. Data ini akan menjadi ukuran kinerja dari server dengan menggunakan teknik server konsolidasi. Selanjutnya data akan disajikan dalam bentuk grafik dan tabeltabel untuk mempermudah dalam memaparkan hasil dari pengujian yang dilakukan.

\section{Hasil dan Pembahasan}

Konsolidasi server adalah teknik yang dibangun dengan memasukkan sejumlah virtual mesin ke dalam sebuah server fisik dengan tepat dan dapat digabungkan menjadi satu servis [1]. Konsolidasi dapat diartikan juga melakukan sentralisasi beban kerja dalam hal ini beberapa server virtual sebagai layanan IAAS kedalam sebuah server fisik yang bertujuan untuk mengurangi biaya.

Konsolidasi Server adalah salah satu alasan utama penyedia layanan cloud dalam menerapkan virtual mesin dan menjadikan beberapa penelitian khususnya migrasi virtual mesin untuk server konsolidasi [2]. Konsolidasi server bertujuan untuk meningkatkan efisiensi pemanfaatan sumber daya komputer dengan mengurangi jumlah server di mana semua fungsi yang sebelumnya ditangani beberapa server berbeda dapat ditangani oleh satu server dengan kapasitas yang lebih besar [3].

Konsolidasi server memiliki tingkat kerumitan yang tinggi, salah satu teknik yang sering digunakan untuk implementasi metode konsolidasi server adalah virtualisasi. Konsolidasi server tentunya memiliki kelemahan dan keuntungan dari berbagai sisi, salah satunya adalah kinerja dari server konsolidasi ataupun efisiensi jika digantikan dengan teknik konsolidasi yaitu server secara virtualisasi.

Dari beberapa paper yang terkait dengan konsolidasi server dapat ditarik sebuah analisa bahwa server konsolidasi adalah pemanfaatan sebuah server dengan kapasitas besar untuk penanganan berbagai kebutuhan server dengan salah satu teknik adalah virtualisasi server atau penggabungan server-server dengan kapasitas yang kecil untuk penanganan masalah kebutuhan beberapa server dengan teknik virtualisasi. Berdasarkan topologi dari penelitian sebelumnya [9], menghasilkan sebuah topologi sesuai dengan Gambar 2

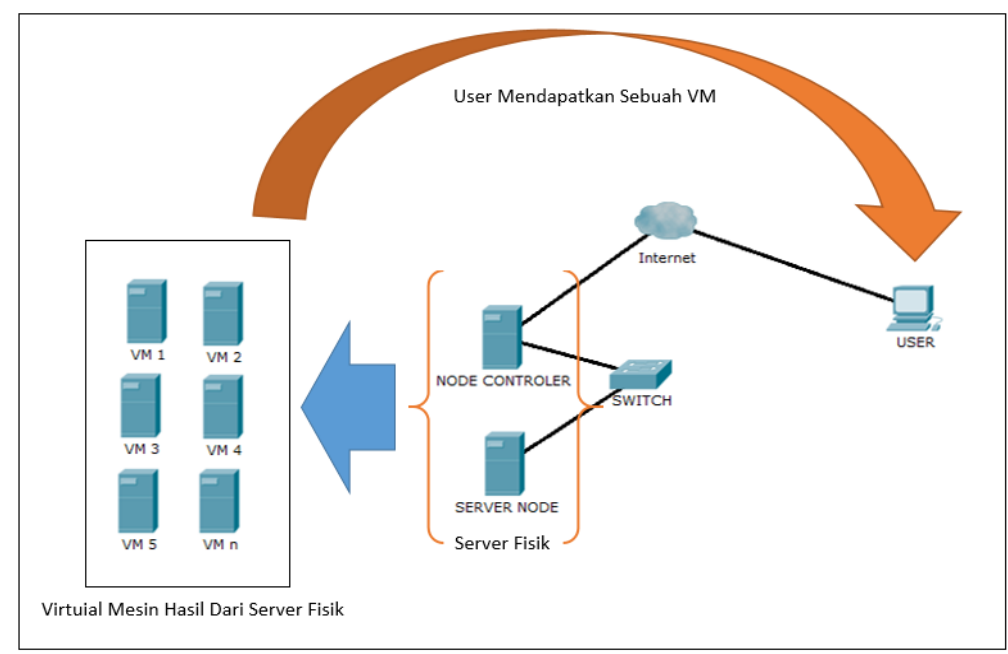

Gambar 2. Topologi Layanan Cloud [9].

Pada Gambar 2 terlihat hasil beberapa virtual mesin yang dijadikan sebagai layanan yang diberikan kepada user. Topologi tersebut dapat dilihat bagaimana konsolidasi server bekerja, di mana kebutuhan beberapa user akan server dapat ditangani dua server, di mana satu server juga digunakan sebagai controller 
dan sebagai penyedia layanan dari infrastruktur itu sendiri. Dari topologi tersebut dihasilkan rancangan arsitektur sebagai berikut:

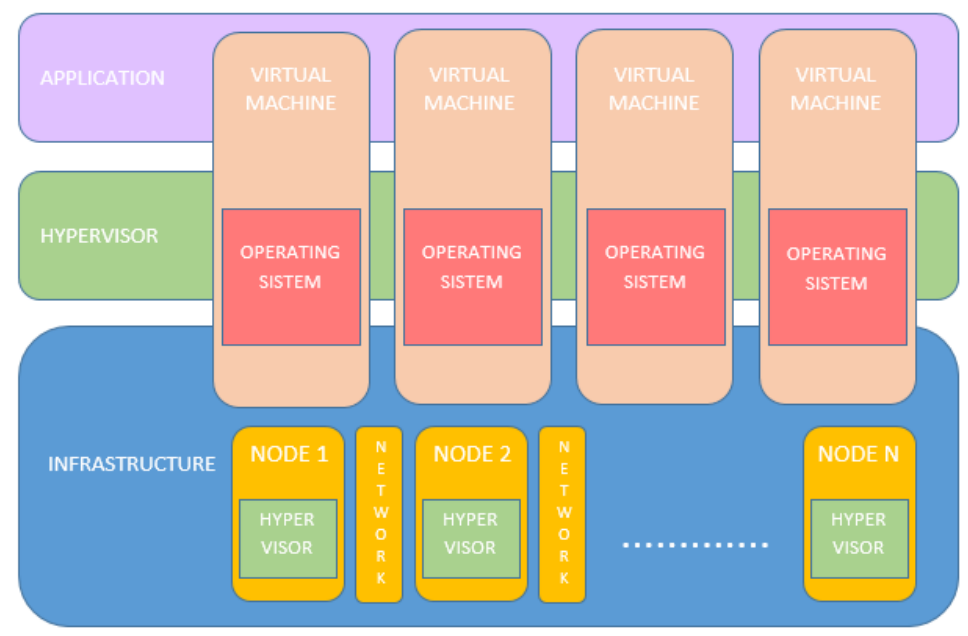

Gambar 3. Arsitektur Konsolidasi Server.

Pada Gambar 3 merupakan hasil dari rekomendasi rancangan arsitektur berdasarkan dari topologi yang dirancang pada Gambar 2. Gambar 3 memperlihatkan beberapa lapisan utama yaitu infrastruktur, hypervisor, dan aplikasi. Kemudian di atas ketiga lapisan tersebut barulah konsolidasi server dibentuk dengan menggunakan virtual mesin (VM). VM ini nantinya dapat dikonfigurasi menjadi server-server dengan tugas yang berbeda-beda.

Pada layer infrastructure dapat dibangun dari sebuah server yang kapasitasnya besar ataupun dari beberapa server yang disatukan menjadi server terpusat. Pada tahap ini ada banyak teknik yang bisa digunakan untuk membentuk satu kesatuan server, di antaranya adalah grid computing. Node ini adalah kumpulan beberapa server di mana dalam membangun grid diperlukan juga hypervisor sebagai sistem operasi yang menggabungkan beberapa sumber daya infrastruktur menjadi satu infrastruktur yang terpusat.

Pada layer hypervisor atau virtual mesin monitor merupakan sebuah platform yang digunakan untuk menjalankan teknik virtualisasi. Dalam hal ini ada beberapa hypervisor yang dapat digunakan. Khusus penelitian ini akan menggunakan Proxmox VE sebagai hypervisor. Proxmox ini masuk dalam kategori Hypervisor tipe 1 disebut juga sebagai baremetal atau native hypervisor. Hypervisor tipe ini berjalan pada perangkat keras. Tipe ini di-install seperti aplikasi yang bundling dengan OS menjadi satu dalam sebuah CPU.

Pada layer Application berfungsi sebagai tempat aplikasi dalam pengelolaan dari sistem cloud nantinya. Layer ini juga berfungsi sebagai antar muka dalam membentuk server-server virtual yang nantinya server-server ini menjadi server konsolidasi.

\section{Kesimpulan}

Kesimpulan dari paper ini adalah dihasilkan berupa arsitektur server konsolidasi yang digunakan untuk penyedia layanan infrastruktur cloud computing. Di mana pada arsitektur ter dapat tiga layer yang diusulkan yaitu layer infrastruktur sebagai penyedia fisik dari server, layer hypervisor sebagai sistem operasi virtualisasi pengelola seluruh infrastruktur fisik, dan yang ketiga adalah layer aplikasi yang berisikan seluruh mesin virtual yang dapat diakses oleh pengguna layanan cloud infrastruktur.

\section{Daftar Pustaka}

[1] L. Tsai and W. Liao, Virtualized Cloud Data Center Networks: Issues in Resource Management. Springer International Publishing, 2016.

[2] B. Di Martino, A. Esposito, and A. Barbato, "High performance cloud: A mapreduce and GPGPU based hybrid approach," Lect. Notes Comput. Sci. (including Subser. Lect. Notes Artif. Intell. Lect. Notes Bioinformatics), vol. 8729, pp. 64-73, 2014.

[3] M. A. Nugroho and R. Kartadie, "Analisis Kinerja Penerapan Container untuk Load Balancing Web Server,” JIPI (Jurnal Ilm. Penelit. dan Pembelajaran Inform., vol. 1, no. 02, pp. 7-15, 2016.

[4] A. Varasteh and M. Goudarzi, "Server Consolidation Techniques in Virtualized Data Centers: A Survey,” IEEE Syst. J., vol. 11, no. 2, pp. 772-783, Jun. 2017.

Arsitektur Konsolidasi Server dengan Virtualisasi untuk Penyedia Layanan Infrastruktur Cloud

(I Gusti Ngurah Wikranta Arsa) 
[5] O. w. Purbo, Membuat sendiri Cloud Computing server menggunakan open source. Jakarta: Penerbit ANDI, 2012.

[6] R. W. Ahmad, A. Gani, S. H. A. Hamid, M. Shiraz, A. Yousafzai, and F. Xia, "A survey on virtual machine migration and server consolidation frameworks for cloud data centers," J. Netw. Comput. Appl., vol. 52, pp. 11-25, 2015.

[7] F. Farahnakian, T. Pahikkala, P. Liljeberg, J. Plosila, and H. Tenhunen, "Multi-agent based architecture for dynamic VM consolidation in cloud data centers," Proc. - 40th Euromicro Conf. Ser. Softw. Eng. Adv. Appl. SEAA 2014, pp. 111-118, 2014.

[8] M. Liu and T. Li, "Optimizing virtual machine consolidation performance on NUMA server architecture for cloud workloads," Proc. - Int. Symp. Comput. Archit., pp. 325-336, 2014.

[9] I. G. N. Wikranta Arsa, "Analisis Overhead Server Cloud Infrastructure pada Proxmox VE Hypervisor,” in E-Proceedings KNS\&I STIKOM Bali, 2017, pp. 310-315. 